\title{
Acute fulminant myoglobinuric polymyositis with picornavirus-like crystals
}

\author{
Y UKIO F UK U Y A MA, TSUNESA B URO A N D O, A N D \\ J U N K O Y O K O T A
}

From the Department of Pediatrics, Tokyo Women's Medical College, Tokyo, Japan

SUMMARY Myoglobinuria was found in an 11 month old girl suffering from fever, dyspnoea, and muscle hypotonia. Muscle biopsy showed focal degenerative necrosis of the muscle fibres. Electronmicroscopically, picornavirus-like crystals were demonstrated in the muscle fibres. These and other findings strongly suggest that she suffered from acute myositis with myoglobinuria probably caused by Coxsackie B6 virus infection. The causal relationship of viral infection (Coxsackie, influenza, or myxo-viruses) and acute or chronic polymyositis with or without myoglobinuria is discussed.

The incidence of myoglobinuria seems to be rare in childhood. In Japan, a few childhood cases of symptomatic myoglobinuria have been reported: they are associated with acute polymyositis (Sakurai et al., 1968), progressive muscular dystrophy (Kitahara and Fukuyama, 1972), or measles (Ando et al., 1974), while an incidence of cryptogenic myoglobinuric myopathy in a sibship has also been described (Shomori et al., 1969).

Recently we have seen a case of acute myoglobinuria which occurred in an 11 month old girl, who was admitted complaining of fever, dyspnoea, and muscle hypotonia. Electronmicroscopic examination of a biopsied muscle specimen revealed picornavirus-like crystals interspersed between myofibrils. The relationship between viral infection and the onset of these symptoms is also discussed.

\section{Case report}

An 11 month old girl was suffering from fever, dyspnoea, and muscular hypotonia. The family history was non-contributory. She was born after a 40 week pregnancy and her birthweight was $3200 \mathrm{~g}$. There was no asphyxia at birth. She suffered from kernicterus as a consequence of severe neonatal jaundice in spite of exchange transfusions 10 days after birth. Spastic diplegia with

Address for correspondence and reprint requests: Dr Yukio Fukuyama, Department of Pediatrics, Tokyo Women's Medical College, 10 Kawada-cho, Shinjuku-ku, Tokyo 162, Japan.

Accepted 5 February 1977 athetosis developed as a sequel so that she had regularly attended our clinic for medical advice and rehabilitation training.

On 22 April 1974 (the first day of illness), she had fever ranging from 38 to $40^{\circ} \mathrm{C}$, but was doing relatively well. On the second day of illness she developed a high temperature $\left(41.8^{\circ} \mathrm{C}\right)$, dyspnoea with cyanosis, and decreased muscle power, and she was brought to our emergency clinic and admitted.

On admission she was a moderately well nourished baby, somnolent but reacting to stimulation. The throat was slightly reddened. Although she had cyanosis and dyspnoea, no abnormality of the chest was found by physical examination. The abdomen was flat. The liver was one fingerbreadth palpable. The spleen was not palpable. Patellar reflex was positive bilaterally and no pathological reflexes were elicited. Although she had usually assumed a spastic posture before the illness, the extremities were now flaccid without any spontaneous active movement. On the third day, she still had fever around $38^{\circ} \mathrm{C}$, but the dyspnoea was somewhat relieved. On 25 April, she excreted dark reddish-brown urine, and hard swelling of both gastrocnemius muscles was noted for the first time.

\section{LABORATORY DATA}

Slight leucocytosis with neutrophilia was noticed. Her urine was brownish; the protein content was $3 \mathrm{~g} / \mathrm{l}$; occult blood test was markedly positive, but there were no abnormal findings in the sediment. The total serum protein was decreased, 
blood urea nitrogen elevated, and serum enzyme activities markedly raised: GOT 2258 units, GPT 1128 units, LDH 2715 units, CPK 68500 units per litre. Haptoglobin value was within normal limits $(74.9 \mathrm{mg} / \mathrm{dl})$. Creatine levels in the serum and urine were both elevated. Cerebrospinal fluid studies yielded normal findings except for elevation of CPK activity to 61 units. Virus isolation from the faeces, spinal fluid or throat swab was attempted, using monkey cells, but without success. Serum complement fixation tests for viruses were all negative except for Coxsackie B6 which showed elevation of the titre to $1 / 16$ on the 27 th day followed by a return to zero on day 180 . Electromyographic exploration on the ninth day showed no diagnostic pattern.

The presence of myoglobin was clearly demonstrated immunologically in the urine but not in the serum on 26 April by the Ouchterlony method (Fig. 1), when the urinary colour was already slightly brownish. Myoglobin could not be detected in serum or urine electrophoretic and visual light absorption tests probably because the concentration of myoglobin in the material was too low.

On the ninth day of the illness, biopsy of the left rectus femoris muscle was carried out. The fundamental structure of muscle fascicles was

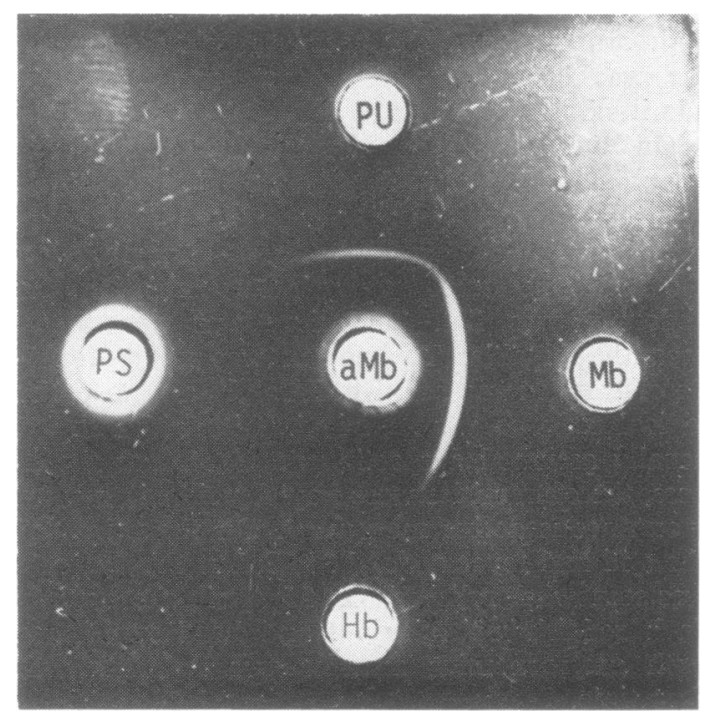

Fig. 1 Immunological demonstration of urinary myoglobin by Ouchterlony method. A precipitation line was clearly visible between the patient's urine and the anti-myoglobin rabbit serum, but not between the patient's serum and anti-myoglobin rabbit serum.

PU = patient's urine (26 April 1974); FS=patient's serum (26 April 1974); $\mathrm{Hb}=$ haemoglobin; $\mathrm{Mb}=$ myoglobin; $\quad \mathrm{aMb}=$ anti-human myoglobin rabbit serum. relatively well preserved in general, but necrotic fibres with or without vacuole and fragmentation were scattered irregularly. There were numerous small opacities in many of the fibres in the cross section, which could indicate the site of abnormal myofibrils though this is unconfirmed (Fig. 2).

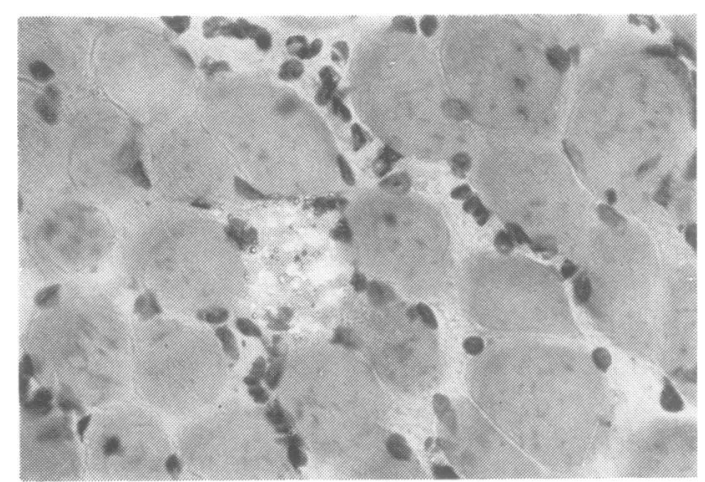

Fig. 2 Light microscopic changes of biopsied femoral muscles. Haematoxylin-eosin.

Occasional waxy degeneration of fibres andत peculiarly conglomerated, coagulated myofibrils were also encountered in other areas. Phagocytosis and central shift of the nuclei of slight degree were also recognised. There was very little peri- vascular and interstitial infiltration of small round cells. Histochemical stains for myosin ATP-ase, SDH and phosphorylase showed normal activity? of enzymes within most muscle fibres. The vacuolated muscle fibres were almost exclusively of type I (Fig. 3). Electron microscopic studies showed a characteristic pattern in which almost normal myofibrils lay alongside those with degenerated amorphous structure and almost completely destroyed $\mathrm{Z}$ bands (Fig. 4a). Figure

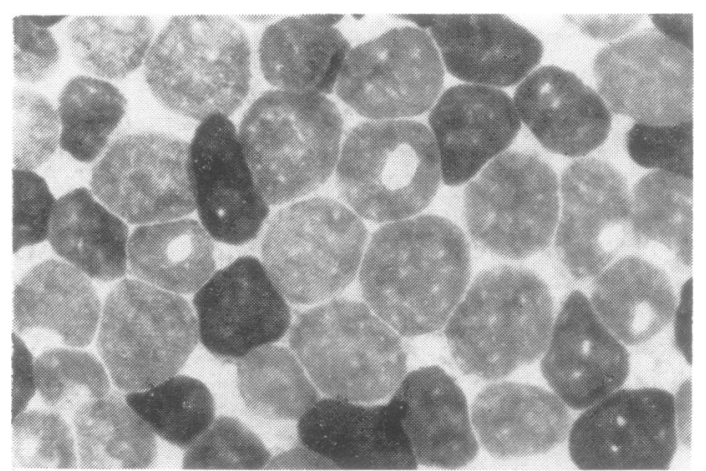

Fig. 3 Myosin ATP-ase staining of biopsied femoral muscle. 

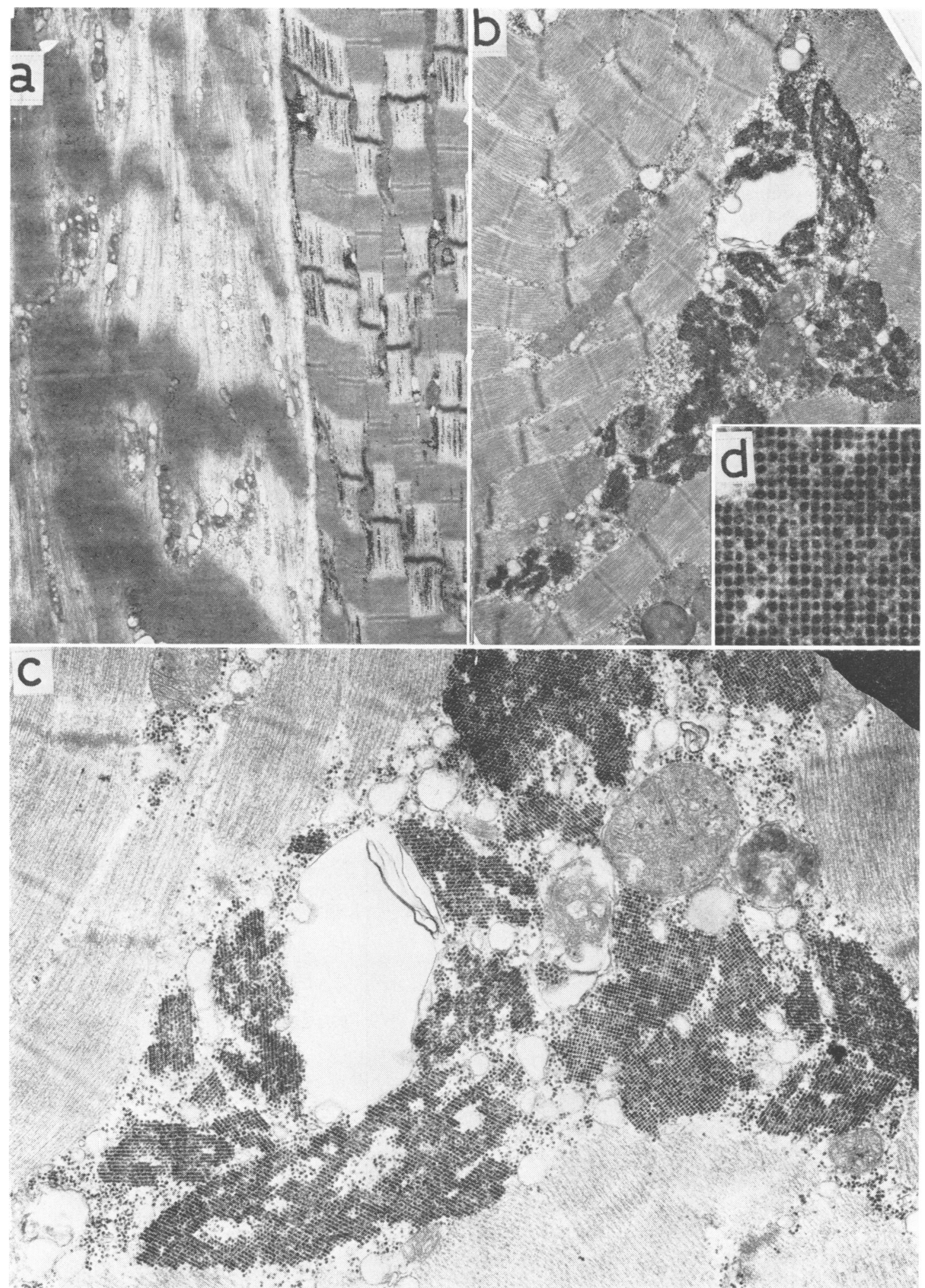

Fig. 4 Ultrastructural findings of biopsied femoral muscles with picornavirus-like crystals. 
4 (b and c) depicts the electronmicrographs of the portion of muscle fibres which appeared to be normal in light microscopy. The structure of myofibrils was relatively well preserved. The large vacuoles may have resulted from the distension of sarcoplasmic vesicles, and in the interspaces between the myofibrils around them there were crystalline structures with high electron density. As Fig. 4d illustrates, they were conglomerates of small particles $(20 \mu \mathrm{m}$ in diameter $)$, and the distance between each particle was $25 \mu \mathrm{m}$. This regular crystalline structure and its morphology suggest that they are picornavirus-like crystals.

\section{CLINICAL COURSE}

The clinical course of the illness is summarised in Fig. 5. The more or less brownish urine was recognised by naked eye between the fourth and sixth days, but distinctly dark reddish brownish urine was excreted only once, on the fourth day. The occult blood in the urine was positive up to the ninth day. Muscle hypotonia and lack of movements were noted until the seventh day of illness, while the muscular tenderness and swelling persisted until the sixteenth day. Dyspnoea, prob- ably due to respiratory muscle paralysis, was present on admission and subsided in a short period with symptomatic therapy. Serum enzyme activities remained at elevated levels for a considerable period; and the CPK level was $445 \mathrm{IU} / 1$ on the nineteenth day. It is of diagnostic significance that these enzymes had increased markedly before the excretion of myoglobin.

\section{Discussion}

The characteristic findings in this patient were: generalised muscle hypotonia with predominance in the lower extremities, presence of myoglobinuria and extremely elevated serum enzyme activities in the early stages of the illness, severe focal degenerative necrosis of the muscle fibres, and electronmicroscopic evidence of picornaviruslike crystals between myofibrils in the biopsied specimen of the rectus femoris muscle.

When urine is brownish in colour and occult blood is present with normal findings in the sediment, differentiation of myoglobinuria from haemoglobinuria should be considered. There are a number of biochemical diagnostic methods in-

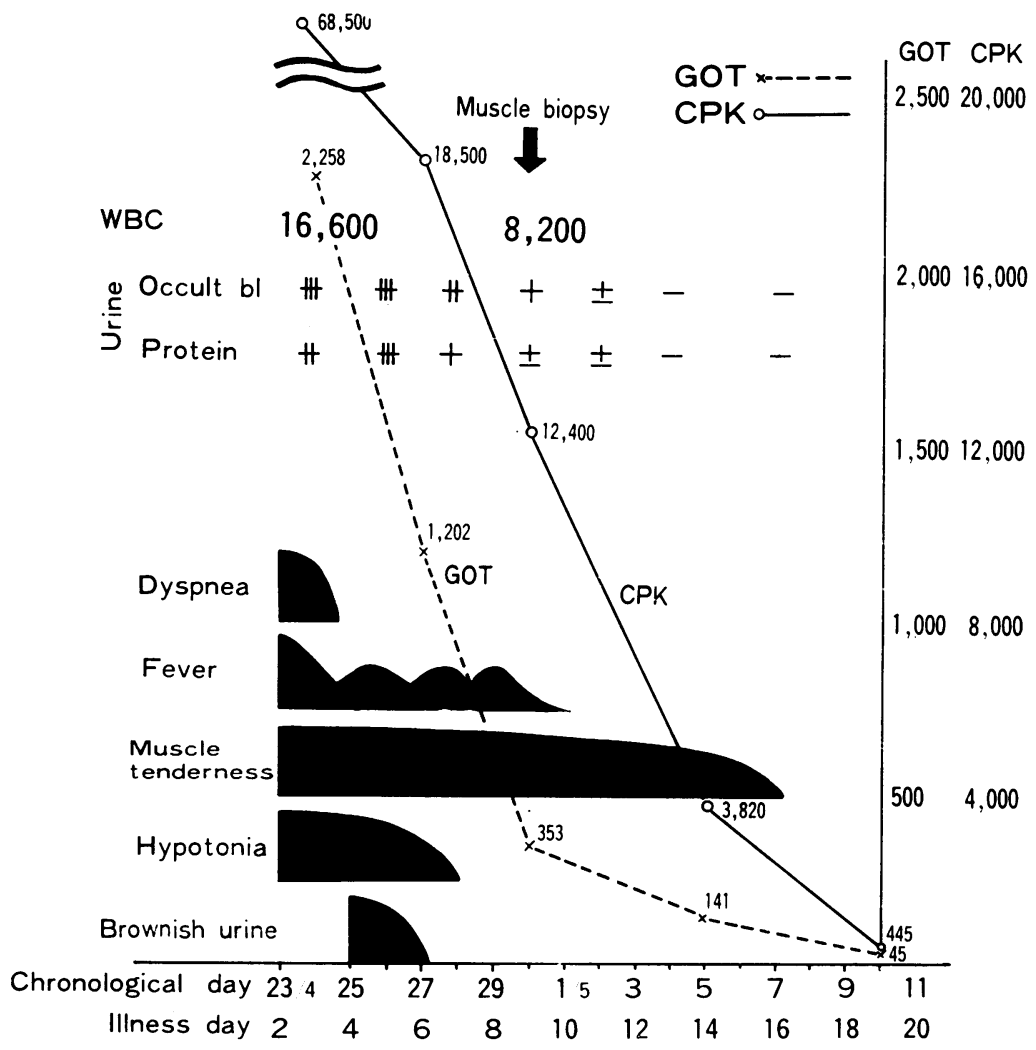

Fig. 5 Clinical course of illness. 
cluding electrophoresis and immunological tests.

Diseases which cause myoglobinuria in childhood seem to be relatively rare. Paroxysmal myoglobinuria was first described by Meyer-Betz in 1910. In 1959, Korein et al., classified two types of myoglobinuria, one triggered by exertional loading and the second occurring secondary to infection. Type 2 is more frequent in children and, up to now, 27 cases have been reported in the world literature (Table). Seven patients who had recurrent episodes were included in the Table though some are of questionable validity. The average age of patients of type 2 was 4 years and 8 months. The ratio by sex was four males to three females. Fever was noted in all except in case 23 and those in which pertinent description was lacking. Cases following symptoms of upper respiratory tract infection were overwhelmingly frequent. There have been 10 fatal cases, so that this disease cannot be regarded as benign.

Myositis apparently due to viral infection is now designated as acute myositis or viral myositis (Middleton et al., 1970; Sato, 1971a; Mejlszenkier et al., 1973). Coxsackie virus has been noted as a provocative agent of viral myositis, but more recently influenzal myositis has been described re- peatedly (Middleton et al., 1970; Simon et al., 1970; Mejlszenkier et al., 1973; Minow et al., 1974). In the recent literature, myoglobinuria secondary to infection (type 2 in the previous classification) is designated more and more frequently as acute myoglobinuria (Simon et al., 1970; Berlin et al., 1974; Minow et al., 1974). We consider that acute myoglobinuria and viral myositis, although different in symptomatic severity, are a pathological entity.

Viruses reportedly responsible for acute myoglobinuria or viral myositis are limited to Coxsackie and influenza viruses. In 1967 Favara et al. isolated Coxsackie A9 virus from a boy aged 2.5 yr with paroxysmal myoglobinuria, and Berlin et al. (1974) found an elevated complement fixation titre for Coxsackie B5 virus in an adult patient with acute myoglobinuria. Simon et al. (1970) described acute myoglobinuria in adults associated with influenza. Middleton et al. (1970) also reported 26 cases of acute myositis of children convalescing from influenza. In 1973, Mejlszenkier et al. reported influenzal myositis occurring in a five year old girl. They described the clinical course of this girl as acute, progressive, with hypotonia predominantly of the lower extremities

Table Review of childhood cases of paroxysmal paralytic myoglobinuria

\begin{tabular}{|c|c|c|c|c|c|c|c|c|c|}
\hline Author & $\begin{array}{l}\text { Age } \\
(y r)\end{array}$ & $\operatorname{Sex}$ & $\begin{array}{l}\text { Age } \\
\text { at } \\
\text { onset } \\
(y r)\end{array}$ & $\begin{array}{l}\text { Effect } \\
\text { of } \\
\text { exertion }\end{array}$ & Episodes & Fever & $\begin{array}{l}\text { Associated } \\
\text { illnesses }\end{array}$ & Fatality & $\begin{array}{l}\text { Muscle } \\
\text { degeneration } \\
\text { histologically } \\
\text { confirmed }\end{array}$ \\
\hline 1. Debré et al. (1934) & 6 & $\mathbf{F}$ & 2.5 & - & multiple & + & $\begin{array}{l}\text { febrile in } \\
\text { disposition }\end{array}$ & - & - \\
\hline 2. Huber et al. (1938) & 4 & $\mathbf{M}$ & 4 & - & 1 & + & r.i.* & - & - \\
\hline 3. Buchanan and Steiner (1951) & 4 & $\mathbf{M}$ & 2 & - & 2 & + & r.i. & + & + \\
\hline 4. Stokes (1953) & 15 & $\mathbf{F}$ & 15 & - & 1 & $?$ & r.i. & + & $?$ \\
\hline 5. Schaar (1955) & $\mathbf{0}$ & $\mathbf{M}$ & 9 & - & 1 & + & pneumonia & - & + \\
\hline 6. Berenbaum et al. (1955) & 10 & $\mathbf{F}$ & 4 & - & 2 & + & surgery & - & + \\
\hline 7. Bowden et al. (1956) & 4 & $\mathbf{M}$ & 1.2 & - & multiple & + & diarrhoea & + & + \\
\hline 8. , , , , , & 8 & $\mathbf{F}$ & 3.6 & - & multiple & + & $\begin{array}{l}\text { diarrhoea } \\
\text { surgery }\end{array}$ & - & - \\
\hline , , , , , , & 6.6 & $\mathbf{M}$ & 6.6 & - & 1 & + & r.i. & - & - \\
\hline , , , , , , & 4 & $\mathbf{F}$ & 4 & - & 1 & $?$ & & + & + \\
\hline 11. Watson and Ainbender (1959) & 6 & $\mathbf{M}$ & 5 & - & 2 & + & & - & + \\
\hline 12. Wheby and Ainbender (1960) & 16 & $\mathbf{F}$ & 4 & + & multiple & + & r.i. & - & + \\
\hline 13. ", ", ," & 15 & $\mathbf{F}$ & 12 & + & multiple & + & r.i. & - & - \\
\hline 14. Hasse and Engel (1960) & 7 & $\mathbf{M}$ & 2.6 & - & multiple & + & $\begin{array}{l}\text { pneumonia } \\
\text { surgery }\end{array}$ & - & + \\
\hline 15. Bailie (1964) & 3 & $\mathbf{M}$ & 1 & - & 2 & + & r.i. & - & not done \\
\hline 16. Bacon (1967) & 14 & $\mathbf{M}$ & 14 & - & 3 & + & r.i. & - & not done \\
\hline 17. Miller and Gross (1967) & 11 & $\mathbf{M}$ & 11 & - & 1 & + & r.i. & - & - \\
\hline 18. Favara et al. (1967) & 2.6 & $\mathbf{M}$ & 2.6 & - & 1 & + & diarrhoea & + & not done \\
\hline 19. , , ,, , & 9 & $\mathbf{M}$ & 3.6 & - & 1 & + & r.i. & - & + \\
\hline 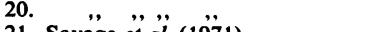 & 0.9 & $\mathbf{M}$ & 0.9 & - & 2 & + & r.i. & + & + \\
\hline 21. Savage et al. (1971) & 3 & $\mathbf{F}$ & 3 & - & 1 & + & r.i. & + & not done \\
\hline , , , , , & 1.6 & $\mathbf{F}$ & 1.6 & - & 1 & + & r.i. & + & + \\
\hline 23. , , ,", ,", & 7 & $\mathbf{M}$ & 7 & - & 1 & - & r.i. & - & + \\
\hline 24. Ghatak et al. (1973) & 3.6 & $\mathbf{M}$ & 3.6 & - & 1 & $?$ & r.i. & + & + \\
\hline 25. , , , , , " & 0.9 & F & 0.9 & - & 1 & + & r.i. & + & + \\
\hline 26. Kitahara and Fukuyama (1972) & 3.3 & $\mathbf{M}$ & 2.4 & + & multiple & + & r.i. & - & + \\
\hline 27. Ando et al. (1974) & 3.8 & $\mathbf{F}$ & 3.8 & - & 1 & + & measles & - & + \\
\hline 28. Current report & 0.11 & $\mathbf{F}$ & 0.11 & - & 1 & + & r.i. & - & + \\
\hline
\end{tabular}

${ }^{*}$ r.i. = respiratory infection. 
which subsided spontaneously within several days. From the viewpoint of therapy and prognosis, they emphasised the importance of differentiation from polymyositis in childhood. In 1974 Minow et al. also reported acute myoglobinuria in adults associated with influenza. These authors were able to demonstrate influenza $\mathbf{A}$ or $\mathbf{B}$ virus as a causative agent by complement fixation tests or by virus isolation. In 1974 we described picornavirus-like crystals in a biopsy specimen in a girl aged 3 years 8 months with paroxysmal myoglobinuria. Furthermore, in polymyositis or dermatomyositis, picornavirus-like crysals were demonstrated in biopsied muscle specimens by Chou and Gutman (1970), Sato (1971b) and BenBassat and Machtey (1972). Sato (1971a) suggested that the acute form of polymyositis may be related to Coxsackie virus and the chronic form to myxovirus. In a more recent report, Sato and Nakamura (1975) also found picornavirus-like crystals in the chronic form, thus suggesting that the pathogenetic relationship is more complicated. We assume that there exists a wide spectrum of inflammatory muscle pathology, extending from the chronic form of polymyositis to acute fulminant myositis with rhabdomyolysis and myoglobinuria. An acute form of polymyositis and acute myositis not accompanied by myoglobinuria would be situated between them. The differences of clinical pathology in these conditions may be determined by the relative importance of primary infectious (viral) and defensive immunological processes in the pathogenesis. It may be considered that a viral infection will play an important role in causing or triggering inflammatory changes in skeletal muscles either directly or indirectly.

Various structures such as nemaline body, honeycomb-like structure originating from the $\mathrm{T}$-tube, or intramitochondrial fibrillar inclusion may appear as a crystalline structure in muscle fibres, but the small round particles with regular crystalline arrangement seen in the present case are quite different morphologically from any of the above, and resemble picornavirus particles. The presence of these crystals between almost normal muscle fibres in the present case may raise some concern. It should be noted that the same picture was observed by Sato and Nakamura (1975), although its meaning remains obscure.

\section{References}

Ando, T., Suzuki, M., and Sato, T. (1974). A case of myoglobinuria associated with measles. Shonika, 15, 981-986.

Bacon, A. E., Jr. (1967). Acute idiopathic rhabdomyolysis with myoglobinuria. Delaware Medical Journal,
39, 302.

Bailie, M. D., (1964). Primary paroxysmal myoglobinuria. New England Journal of Medicine, 271, 186-189.

Ben-Bassat, M., and Machtey, I. (1972). Picornaviruslike structures in acute dermatomyositis. American Journal of Clinical Pathology, 58, 245-249.

Berenbaum, M. C., Birch, C. A., and Moreland, J. D. (1955). Paroxysmal myoglobinuria. Lancet, 1, 892-896.

Berlin, B. S., Simon, N. M., and Rovner, R. N. (1974). Myoglobinuria precipitated by viral infection. Journal of the American Medical Association, 227, 1414-1415.

Bowden, D. H., Fraser, D., Jackson, S. H., and Walker, N. F. (1956). Acute recurrent rhabdomyolysis (paroxysmal myohemoglobinuria). Medicine, 35, 335-353.

Buchanan, D., and Steiner, P. E. (1951). Myoglobinuria with paralysis (Meyer-Betz disease). Archives of Neurology and Psychiatry (Chicago), 66, 107109.

Chou, S. M., and Gutman, L. (1970). Picornaviruslike crystals in subacute polymyositis. Neurology (Minneapolis), 20, 205-213.

Debré, R., Gernez, C., and See, G. (1934). Crises myopathiques paroxystiques avec hemoglobinurie Societés Médicales des Hôpitaux de Paris, 50, 16401649.

Favara, B. E., Vawter, G. F., Wagner, R., and Porter, E. (1967). Familial paroxysmal rhabdomyolysis associated with myoglobinuria. American Journal of Medicine, 42, 196-207.

Ghatak, N. R., Erenberg, G., and Hirano, A. (1973). Idiopathic rhabdomyolysis in children. Journal of the Neurological Sciences, 20, 253-268.

Hasse, G. R., and Engel, A. G. (1960). Paroxysmal recurrent rhabdomyolysis. Archives of Neurology, 2, 410-419.

Huber, J., Florand, J., Lievre, J. A., and Neret (Mme). (1938). Crises myopathiques paroxystiques avec hemoglobinurie. Bulletin et Memoire des Societés Médicales des Hôpitaux de Paris, 54, 725-730.

Kawai, N., Nakano, M., and Miyoshi, K. (1971). Myoglobin. Kokyu To Junkan, 19, 452-459.

Kitahara, H., and Fukuyama, Y. (1972). A case of progressive muscular dystrophy associated with paroxysmal myoglobinuria. Journal of Tokyo Women's Medical College, 42, 1016-1022.

Korein, J., Coddon, D. R., and Mowrey, F. H. (1959). The clinical syndrome of paroxysmal paralytic myoglobinuria. Neurology (Minneapolis), 9, 767785.

Mejlszenkier, J. D., Safran, A. P., Healy, J. J., Embree, L., and Quellette, E. M. (1973). The myositis of influenza. Archives of Neurology, 29, 441-443.

Meyer-Betz, F. (1910). Beobachtungen an einem eigenartigen mit muskellahmangen verbundenen fall von hamoglobinurie. Deutsches Archiv für Klinische Medizin, 101, 85-127.

Middleton, P. J., Alexander, R. M., and Szymanski, 
M. T. (1970). Severe myositis during recovery from influenza. Lancet, 2, 533-535.

Miller, B. H., and Gross, J. S. (1967). Acute rhabdomyolysis with myoglobinuria. Virginia Medical Monthly, 94, 213-218.

Minow, R. A., Gorbach, S., Jchnson, B. L., and Dornfeld, L. (1974). Myoglobinuria asscciated with influenza A infection. Annals of Internal Medicine, 80, 359-361.

Sakurai, H., Taniguchi, T., and Sato, T. (1968). Three cases of polymyositis. Acta Paediatrica Japonica, 72, 821 .

Sato, T. (1971a). Viral myositis. Naika (Tokyo), 28, 407-411.

Sato, T. (1971b). On changes of muscle nuclei in viral myositis. Recent Advances in Research of the Nervous System, 15, 109-120.

Sato, T., and Nakamura, N. (1975). Myositis and viruses. Naika (Tokyo), 35, 239-246.

Savage, D. C. L., Forbes, M., and Pearce, G. W.
(1971). Idiopathic rhabdomyolysis. Archives of Disease in Childhood, 46, 594-607.

Schaar, F. E. (1955). Paroxysmal myoglobinuria. American Journal of Diseases of Children, 89, 2330.

Shomori, T., Shomori, A., Fukui, A., Kawashima, R., and Hamada, Y. (1969). A sib case of myoglobinuric myopathy. Clinical Neurology (Tokyo), 9, 109.

Simcn, N. M., Rovner, R. N., and Berlin, B. S. (1970). Acute mycglobinuria associated with type A2 (Hong Kong) influenza. Journal of the American Medical Association, 212, 1704-1705.

Stckes, W. (1953). Quoted by Savage, Forbes, and Pearce (1971).

Watson, R. J., and Ainbender, E. (1959). Qucted by Savage, Forbes, and Pearce (1971).

Wheby, M. S., Henry, S., and Miller, J. R. (1960). Idicpathic paroxysmal myoglobinuria. American Journal of Medicine, 29, 599-610. 